\title{
Analisis Faktor-Faktor yang Mempengaruhi Persepsi Masyarakat dalam Pembangunan Hutan Tanaman Rakyat pada KPH Gedong Wani
}

\author{
Dian Novayanti1 ${ }^{1,}$, Irwan Sukri Banuwa', Rahmat Safe'i1, Christine Wulandari', \\ Indra Gumay Febryano ${ }^{1}$ \\ ${ }^{1}$ Program Studi Magister IImu Kehutanan Fakultas Pertanian Universitas Lampung \\ JI. Prof. Dr. Soemantri Brodjonegoro No. 1 Bandar Lampung 35145 \\ *Email: diannova_nova@ymail.com
}

\begin{abstract}
One effort to reduce environmental damage is the launching of the Social Forestry Program by the Ministry of Environment and Forestry. One such program is Community Plantation Forest (HTR). Farmers' perception of a program is the main basis for the willingness to participate in a program. The purpose of this study are: 1) Knowing the perception of the community, and 2) Knowing the factors that affect the public perception of the HTR development program in KPH Gedong Wani. The research was conducted in Sinar Ogan Village, Srikaton, Jati Indah, Jati Baru, and Budi Lestari, which is the recipient village of IUPHHK-HTR. Sampling technique using stratified random sampling and obtained as many as 95 respondents by interview method. To know the factors that influence perception using multiple regression. The results of this study show the public perception on the development of HTR in the medium category. Factors that have significant effect on public perception are formal education, informal education, HTR land area, monthly income, availability of information, and intensity of counseling.
\end{abstract}

Keywords: Perception; HTR; KPH

DOl: http://dx.doi.org/10.24259/jhm.v9i2.2861

\section{PENDAHULUAN}

Kesatuan Pengelolaan Hutan (KPH) Gedong Wani merupakan salah satu otoritas pengelolaan hutan di Provinsi Lampung yang seluruh kawasannya telah diokupasi oleh masyarakat perambah. Di dalam kawasan seluas 30.324 hektar kini tidak dapat lagi dijumpai areal yang berhutan melainkan berupa $70,6 \%$ pertanian lahan kering; $13,71 \%$ kebun campuran; $8,62 \%$ pemukiman; $6,72 \%$ lahan terbuka dan $0,28 \%$ berupa industri skala besar pengolahan hasil pertanian seperti kepala sawit, tapioka dan lain-lainnya. Bahkan di kawasan hutan produksi ini tercatat ada 39 desa definitif dalam 11 kecamatan definitif lengkap dengan fasilitas umum termasuk jaringan jalan beraspal hotmix, kantor desa, kantor camat, sekolah dasar sampai perguruan tinggi, puskesmas, pasar, tempat ibadah, polsek, koramil dan sebagainya (Dishut Provinsi Lampung, 2013). Permasalahan ini berakar dari pertumbuhan penduduk yang semakin meningkat. Pertambahan penduduk menuntut tercukupinya kebutuhan pangan, kebutuhan kayu bakar, kebutuhan kayu pertukangan, dan tempat pemukiman. (Senoaji, 2011), Wulandari (2010) juga menambahkan bahwa masalah degradasi lingkungan yang terjadi sering kali berpangkal pada komponen manusia.

Untuk mengurangi laju kerusakan hutan sekaligus meningkatkan keterlibatan masyarakat sekitar hutan dalam pengelolaan hutan, maka pemerintah melalui Kementerian Lingkungan Hidup dan Kehutanan mencanangkan program Perhutanan Sosial. Tujuan pengembangan perhutanan sosial adalah meningkatkan peran serta masyarakat dalam mengelola hutan sehingga dapat meningkatkan taraf kehidupan masyarakat sekitar (Sumanto, 2009). Dasar hukum pelaksanaan program Perhutanan Sosial adalah Peraturan Menteri Lingkungan Hidup dan Kehutanan Nomor P.83/MENLHK/SETJEN/ KUM.1/10/2016 tentang Perhutanan Sosial. Di dalam peraturan tersebut terdapat skema-skema 
pengelolaan hutan berbasis masyarakat seperti Hutan Desa, Hutan kemasyarakatan, hutan tanaman rakyat, hutan rakyat, hutan adat, dan kemitraan kehutanan.

Saat ini, Kementerian Lingkungan Hidup dan Kehutanan telah memberikan Izin Pemanfaatan Hasil Hutan Kayu pada Hutan Tanaman Rakyat (IUPHHK-HTR) kepada 5 Desa yaitu Desa Budi Lestari, Desa Sinar Ogan, Desa Jati Baru, Desa Srikaton, dan Desa Jati Indah yang terletak di Register 40 KPH Gedong Wani Kecamatan Tanjung Bintang, Kabupaten Lampung Selatan, Provinsi Lampung. Permohonan untuk IUPHHK-HTR ini telah dilakukan oleh masyarakat sejak tahun 2014 dan baru diberikan ijin oleh Kementerian pada Bulan Maret tahun 2017. Sekalipun demikian, dalam implementasinya skema HTR menjadi persoalan lain yang tidak sederhana dalam kawasan hutan tersebut. Umumnya para petani tidak puas bila hanya diakui sebagai pemegang hak guna atas semua lahan yang telah mereka kuasai sekarang. Mereka umumnya menginginkan agar menjadi hak milik melalui suatu proses pelepasan kawasan hutan. Hal ini menyebabkan masyarakat tidak mau terlibat atau berpartisipasi dalam kegiatan HTR. Keterlibatan masyarakat turut mempengaruhi kesuksesan suatu program. Persepsi masyarakat terhadap suatu program merupakan landasan atau dasar utama bagi timbulnya kesediaan untuk ikut terlibat atau berpatisipasi dalam suatu program tersebut.

Faktor penentu keberhasilan program HTR antara lain kesiapan aspek sosial yaitu kesempatan, kemauan, dan kemampuan masyarakat harus diperhatikan (Ekawati dkk, 2008) yang secara keseluruhan akan mempengaruhi ketertarikan masyarakat. Persepsi seseorang terhadap sesuatu akan mempengaruhi perilakunya (behavior) salah satunya dalam wujud pengambilan keputusan (FabraCrespo, 2012). Sebagai langkah awal menuju suatu proses kerjasama antar pelaku, perlu dilakukan studi tentang persepsi petani penggarap terhadap program HTR yang telah dilakukan sampai saat ini (Desmiwati, 2016).

\section{METODE PENELITIAN}

\subsection{Tempat dan Waktu}

Penelitian ini dilaksanakan dari bulan Maret sampai Juli 2017 di Desa Budi Lestari, Desa Sinar Ogan, Desa Jati Baru, Desa Srikaton, dan Desa Jati Indah yang merupakan areal HTR di Register 40 KPH XIV Gedong Wani, Kecamatan Tanjung Bintang, Kabupaten Lampung Selatan, Provinsi Lampung. Pemilihan lokasi penelitian dilakukan secara sengaja (purposive) dengan pertimbangan bahwa lokasi tersebut telah memiliki ijin pemanfaatan hasil hutan kayu hutan tanaman rakyat (IUPHHKHTR) sejak tahun 2017 sehingga program HTR dapat dilaksanakan.

\subsection{Pengolahan dan Analisis Data}

\section{a. Persepsi Masyarakat Terhadap Program Pembangunan Hutan Tanaman Rakyat}

Dalam penilaian tinggi rendahnya persepsi masyarakat terhadap program pembangunan hutan tanaman rakyat, untuk mengetahuinya dipergunakan indikator :

1. Penilaian masyarakat terhadap manfaat hutan tanaman rakyat

2. Penilaian masyarakat terhadap jenis tanaman HTR

3. Penilaian masyarakat terhadap persyaratan perijinan HTR

4. Penilaian masyarakat terhadap proses perijinan HTR

5. Penilaian masyarakat terhadap pewarisan HTR

6. Penilaian masyarakat terhadap hak dan kewajiban HTR

7. Penilaian masyarakat terhadap kelembagaan HTR 
8. Penilaian masyarakat terhadap sosialisasi HTR

9. Penilaian masyarakat terhadap tenaga pendamping HTR

10. Penilaian masyarakat terhadap dukungan HTR

Pertanyaan masing-masing penilaian berjumlah 3 buah dengan indeks skor jenjang 3 . Sedangkan untuk nilai tingkat persepsi secara keseluruhan dilakukan dengan menjumlahkan 30 pertanyaan.

\section{b. Faktor-faktor yang Mempengaruhi Persepsi Masyarakat}

Untuk data faktor internal dan eksternal yang mempengaruhi persepsi masyarakat, dicatat dan disesuaikan dengan variabelnya dan dihitung skornya untuk mengetahui kategori rendah, sedang atau tinggi. Kemudian dilakukan analisis deskriptif kualitatif.

Untuk mengetahui hubungan atau pengaruh variabel bebas terhadap variabel tidak bebas dilakukan dengan menggunakan analisis regresi dengan model fungsi persepsi masyarakat hutan tanaman rakyat sebagai berikut:

$\hat{Y}=f(X 1, X 2, X 3, X 4, X 5, X 6, X 7, X 8, X 9)$

Keterangan:

$\hat{Y}=$ Persepsi masyarakat

$\mathrm{X} 1=\mathrm{Umur}$

$\mathrm{X} 2=$ Pendidikan Formal

$\mathrm{X} 3$ = Pendidikan Informal

$X 4$ = Luas Lahan Pencadangan

$\mathrm{X} 5$ = Jarak ke lokasi pencadangan

$\mathrm{X} 6$ = Pendapatan

$\mathrm{X} 7$ = Jumlah Tanggungan

$X 8=$ Ketersediaan Info

$\mathrm{X} 9=$ Intensitas Penyuluhan

Kemudian dilanjutkan dengan uji $\mathrm{F}$ dan Uji t. Uji F dipergunakan untuk melihat pengaruh variabel bebas secara bersama-sama terhadap variabel tidak bebas. Sedangkan untuk melihat pengaruh variabel bebas terhadap variabel tidak bebas secara sendiri-sendiri dipergunakan uji t.

\section{HASIL DAN PEMBAHASAN}

\subsection{Persepsi Masyarakat Terhadap Pembangunan HTR}

Menurut Robbin (2006) persepsi merupakan penilaian atau tanggapan seseorang terhadap obyek atau kegiatan tertentu. Persepsi seseorang terhadap suatu obyek akan positif apabila sesuai dengan kebutuhannya, sebaliknya akan negatif apabila bertentangan dengan kebutuhan orang tersebut. Selain itu mereka merasa tidak dirugikan dengan adanya pembangunan HTR sehingga persepsi mereka tinggi. 




Gambar 1. Persepsi Responden terhadap Pembangunan HTR

Persepsi responden yang tergolong sedang sebanyak 83,2\%. Pada kondisi seperti ini, responden yang memberikan persepsi sedang dapat bersifat mendukung kegiatan pembangunan HTR atau bahkan dapat menghambat kegiatan pembangunan HTR. Persepsi yang sedang ini disebabkan karena responden hanya dapat merasakan sebagian manfaat positif dengan adanya pembangunan HTR. Sedangkan sebanyak 16,8 \% responden masuk dalam kategori persepsi rendah. Alasan responden memiliki persepsi rendah adalah mereka kurang setuju dengan ketentuan yang ada sudah ditentukan pada ketentuan HTR yang tertuang dalam Peraturan Menteri Lingkungan Hidup dan Kehutanan Nomor P.83/MENLHK/SETJEN/ KUM.1/10/2016 tentang Perhutanan Sosial.

Aturan yangdibuat pemerintah pusat semestinya disertai dengan pembuatan peraturan daerah dan aturan lainnyayang menjadi kewenangan pemerintah pada tingkat daerah/kabupaten, sehingga tercipta sinergitas penyelenggaraan pemerintahan antara pemerintah pusat dan daerah. Seperti aturan bahwa lahan HTR yang sudah dimiliki oleh masyarakat, tidak dapat diwariskan kepada siapapun ketika nantinya orang tersebut meninggal dunia, dan beberapa aturan lain yang mereka kurang setuju yang akan dibahas dalam uraian berikut ini.

\section{a. Persepsi Masyarakat terhadap Manfaat HTR}

Masyarakat mengaku dengan adanya ijin, mereka merasa nyaman dan aman dalam mengelola hutan. Berdasarkan data yang didapat dilapangan responden pada keempat Desa yaitu Budi Lestari, Sinar Ogan, Jati Baru dan Srikaton memiliki tingkat persepsi sedang, sedangkan persepsi tinggi hanya di temui di Desa Jati Indah. Persepsi terbentuk dikarenakan masyarakat masih berpendapat bahwa saat ini kegiatan HTR masih lebih menguntungkan pemerintah dibandingkan dengan keuntungan yang diperoleh masyarakat.

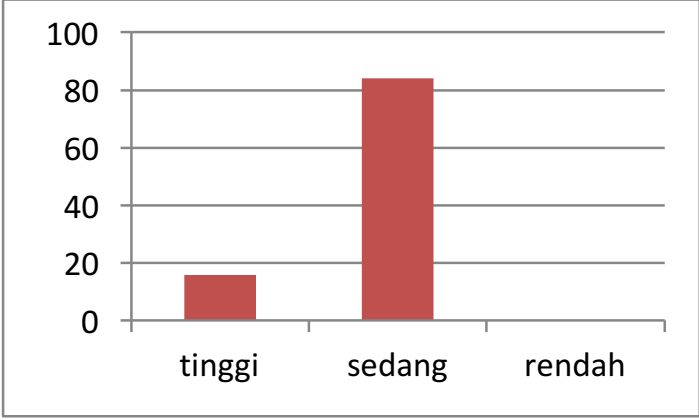

Gambar 2. Persepsi Masyarakat terhadap Manfaat dari HTR 
Total keseluruhan terdapat $84,2 \%$ responden yang memiliki tingkat persepsi sedang dan sebanyak $15,8 \%$ responden memiliki tingkat persepsi yang tinggi terhadap manfaat adanya HTR. Dengan adanya HTR ini, masyarakat mendapatkan akses pengelolaan hutan secara legal. Perkembangan kegiatan HTR di lokasi penelitian merupakan tahap awal karena masyarakat baru mendapatkan ijin usaha pengelolaan hutan-hutan tanaman rakyat pada tanggal 1 Maret 2017 yang lalu sehingga manfaat yang dimaksud dalam penelitian ini lebih ditujukan pada harapan masyarakat dengan mengikuti program pembangunan HTR. Dengan adanya program pembangunan HTR ini, masyarakat juga berharap nantinya mereka mendapatkan manfaat berupa adanya pemberian bibit, pemberian pupuk, pemberian pelatihan untuk meningkatkan hasil panen mereka. Dengan adanya pemberian tersebut, diharapkan masyarakat dapat meningkatkan ekonomi mereka.

\section{b. Persepsi Masyarakat terhadap Jenis Tanaman}

Jenis tanaman yang dapat dikembangkan di areal HTR didasarkan pada Peraturan Menteri Kehutanan Republik Indonesia Nomor P.55/Menhut-II/2011 tentang Tata Cara Permohonan Izin Usaha Pemanfaatan Hasil Hutan Kayu pada Hutan Tanaman Rakyat dalam Hutan Tanaman. Jenis tanaman pokok yang dapat dikembangkan untuk pembangunan usaha pemanfaatan hasil hutan kayu HTR terdiri dari: a. tanaman sejenis; atau b. tanaman berbagai jenis. Jenis tanaman pokok sejenis sebagaimana dimaksud adalah tanaman hutan berkayu yang hanya terdiri satu jenis (species) dan varietasnya. Jenis tanaman pokok berbagai jenis sebagaimana dimaksud adalah tanaman hutan berkayu yang dikombinasikan dengan tanaman budidaya tahunan yang berkayu antara lain karet, tanaman berbuah, bergetah dan pohon penghasil pangan dan energi. Tanaman budidaya tahunan paling luas $40 \%$ (empat puluh persen) dari areal kerja dan tidak didominasi oleh satu jenis tanaman.

Di lokasi penelitian seperti di Desa Budi Lestari, lahan di dominasi tanaman karet, akasia, sawit, dan sengon yang diselang seling dengan acasia. Di Desa Sinar Ogan lahan ditanami karet, acasia, sawit, palawija. Di Desa Jati Baru lahan ditanami karet,acasia, sawit, dan palawija. Desa Srikaton seluruh areal sudah dimanfaatkan dengan ditanami karet $80 \%$ sisanya ditanami sengon, acasia, singkong, jagung, dan padi. Sedangkan Desa Jati Indah lahan nya ditanami karet, jati, dan acasia.

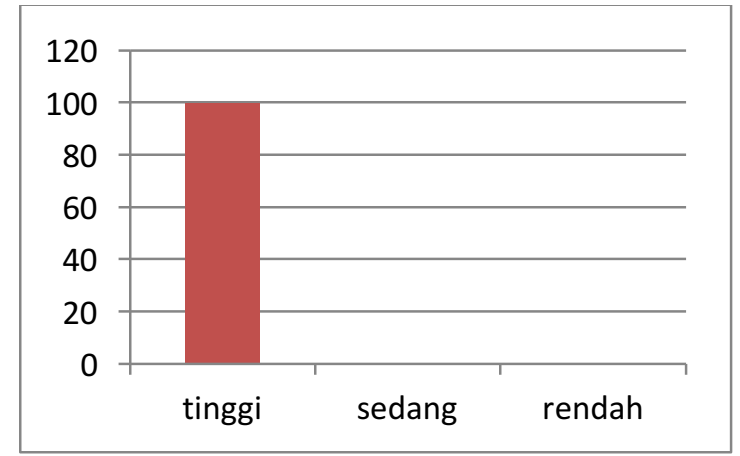

Gambar 3. Persepsi Masyarakat terhadap Jenis Tanaman

Dari hasil penelitian, sebanyak $100 \%$ responden setuju dengan ketentuan terhadap jenis tanaman dengan memberikan penilaian dengan kategori persepsi tinggi. Namun, bila dilihat dari jenis tanaman yang masyarakat usahakan di lahan hutan tanaman rakyat, dalam jangka waktu 5 tahun belum dapat memenuhi kebutuhan industri kayu karena produksi yang dihasilkan sebagian besar 
adalah getah karet, dan untuk acasia serta sengon sebagian besar masih berumur sekitar 2 sampai 3 tahun.

\section{c. Persepsi Masyarakat terhadap Persyaratan Perijinan}

Dari hasil penelitian, menunjukkan bahwa sebanyak 75,8 \% responden (gambar 4) memberikan persepsi yang tinggi terhadap persyarakatan perijinan. Berdasarkan data hasil penelitian masyarakat pada Desa Budi Lestari, Sinar Ogan dan Jati Baru memiliki persepsi yang tinggi terhadap persyaratan perizinan. Masyarakat pada desa tersebut berpendapat bahwa persyaratan yang harus dikumpulkan mudah untuk dipenuhi. Mereka hanya diminta untuk mengumpulkan KTP, yang selanjutnya kepala desa akan mengeluarkan surat keterangan domisili.

Sedangkan masyarakat pada Desa Srikaton dan Jati Indah memiliki persepsi yang sedang terhadap proses perizinan, hal tersebut dikarenakan terjadinya migrasi pendatang sehingga sebagian penduduk tidak mempunyai surat keterangan ijin tinggal. Hal ini mengacaukan administrasi desa. Dengan demikian perlu dilakukan penguatan kelembagaan pemerintahan desa dan pengawasan dari institusi di atasnya.

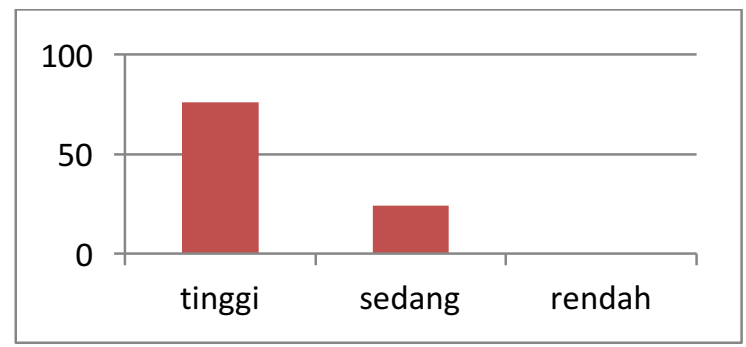

Gambar 4. Persepsi Masyarakat terhadap Persyaratan Perijinan

Dalam gambar 4, sebanyak $24,2 \%$ responden tergolong memiliki persepsi yang sedang terhadap persyaratan perijinan. Salah satu persyaratan perijinan adalah adanya peta areal, sedangkan sampai perijinan IPUHHK-HTR keluar, masyarakat mengatakan bahwa mereka belum membuat peta areal. Adanya persyaratan perijinan yang mudah tersebut menyebabkan masyarakat dengan mudah untuk bergabung menjadi anggota HTR dan dapat ikut melaksanakan pembangunan HTR.

\section{d. Persepsi Masyarakat terhadap Proses Perijinan}

Dalam gambar 5, sebanyak 93,7 \% responden memberikan persepsi yang sedang terhadap proses perijinan. Mereka berpendapat bahwa walaupun persyaratan bagi masyarakat yang ingin mengajukan ijin pemanfaatan HTR (IUPHHK-HTR) mudah dipenuhi, waktu yang dibutuhkan agar ijin IUPHHK-HTR keluar tergolong lama. Usulan pencadangan HTR telah dilakukan mulai tahun 2014. Kelima Desa tersebut, baru akhirnya mendapatkan ijin IUPHHK-HTR pada bulan Maret 2017 dan diserahkan melalui Kepala Dinas Kehutanan Provinsi Lampung. 


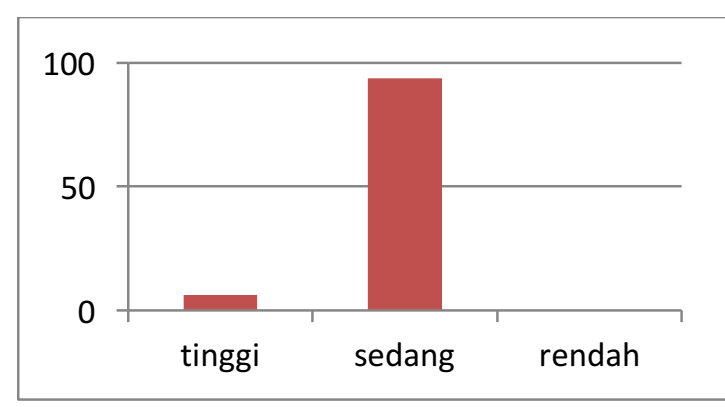

Gambar 5. Persepsi Masyarakat terhadap Proses Perijinan

Untuk biaya pengurusan, responden hanya mengeluarkan sedikit biaya atau bahkan tidak sama sekali karena untuk pengumpulan kartu identitas, pendamping yang ditunjuk oleh KPH Gedong Wani mendatangi rumah warga yang akan mengajukan ijin. Sebanyak 6,3\% responden memiliki persepsi yang tinggi terhadap proses perijinan karena masyarakat tidak mengetahui bagaimana proses perijinan tersebut. Masyarakat yang memiliki persepsi tinggi ini mengatakan bahwa mereka tidak mengikuti proses perijinan yang berjalan dan secara tiba-tiba perijinan langsung keluar.

\section{e. Persepsi Masyarakat terhadap Pewarisan}

Sesuai dengan Peraturan Menteri Lingkungan Hidup dan Kehutanan Republik Indonesia Nomor P.83.MENLHK/SETJEN/KUM.1/10/2016 tentang perhutanan sosial, IUPHHK-HTR berlaku untuk jangka 35 tahun dan tidak dapat diwariskan. Masyarakat berpendapat hal ini tidak adil untuk mereka, karena mereka merasa bahwa lahan tersebut telah turun temurun dikelola oleh mereka dan sebagian masih menganggap bahwa lahan tersebut sebagai hak milik. Dengan adanya ketentuan bahwa ijin IUPHHK HTR tidak dapat diwariskan, maka ketika pemegang ijin telah meninggal dunia, ijin harus dikembalikan kepada negara. Seseorang hanya dapat mengelola lahan tersebut sampai orang tersebut meninggal dunia walaupun ijin tersebut setelah 35 tahun dapat diperpanjang lagi.

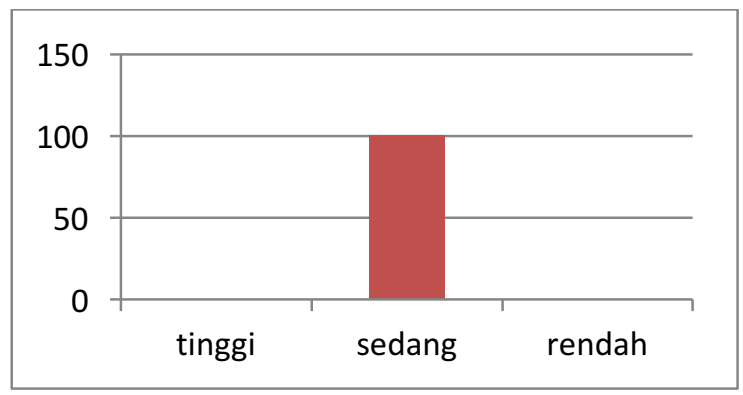

Gambar 6. Persepsi Masyarakat terhadap Pewarisan

Dari gambar 6, secara keseluruhan sebanyak 100\% responden kurang setuju dengan ketentuan tersebut. Alasannya karena mereka telah lama mengelola lahan dan menjadi sumber penghasilan tetap bagi mereka. Mereka sangat berharap bahwa lahan tersebut dapat diwariskan kepada anak cucu mereka agar menjadi jaminan kehidupan ekonomi mereka.

Berdasarkan uraian tersebut, maka sebaiknya aturan ini disesuaikan dengan kondisi dan kebutuhan masyarakat. Pemerintah dapat memberikan kesempatan kepada ahli waris untuk mengelola 
hutan sampai jangka waktu yang telah diberikan pada saat pemegang ijin telah meninggal dunia asalkan tunduk pada ketentuan yang telah disepakati sebelumnya.

\section{f. Persepsi Masyarakat terhadap Hak dan Kewajiban}

Hak dan kewajiban pemegang ijin IUPHHK-HTR telah diatur dalam P.83/MENLHK/SETJEN/KUM.1/10/2016 dan juga telah tercantum di SK IUPHHL-HTR yang telah diterima oleh masing-masing ketua gapoktan. Dari hasil wawancara seperti pada gambar 7 , sebanyak $2,1 \%$ responden memberikan nilai sedang dan sisanya sebanyak 97,9 memberikan nilai rendah.

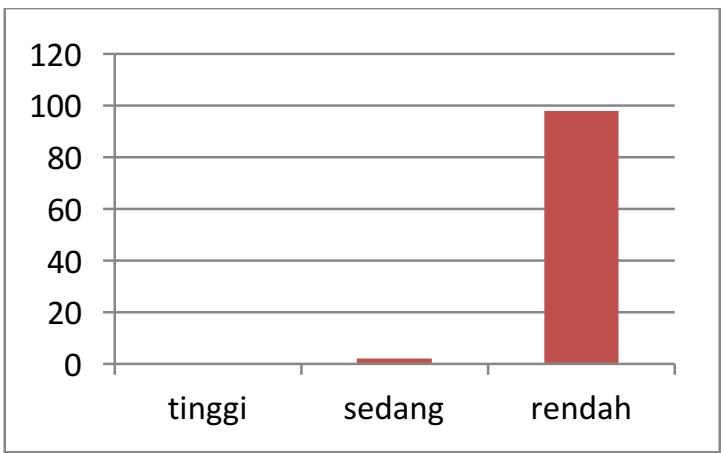

Gambar 7. Persepsi Masyarakat terhadap Hak dan Kewajiban

Pada saat dilakukan wawancara, beberapa responden mengaku belum pernah melihat SK IUPHHK-HTR yang telah diterima oleh ketua gapoktan mereka. Namun demikian, ketika diberi penjelasan bahwa salah satu kewajiban mereka adalah menyusun RKU dan RKT mereka tidak merasa keberatan. Mereka meminta untuk dibantu pihak seperti akademisi dan penyuluh untuk menyusun RKU dan RKT.

Adanya persepsi masyarakat yang tergolong rendah dan sedang terhadap hak dan kewajiban dikarenakan adanya kewajiban membayar provisi sumber daya hutan. Selain itu, masalah hak yang diterima masyarakat seperti mendapatkan fasilitasi dalam hal pembiayaan dan akses pasar juga belum didapatkan.

\section{g. Persepsi Masyarakat terhadap Kelembagaan Hutan}

Kelompok tani dibuat dengan tujuan untuk memudahkan pengurusan administrasi dalam pengajuan ijin HTR, memudahkan transfer informasi mengenai HTR, dan memudahkan administrasi pengajuan pinjam dana bergulir untuk pembangunan HTR nantinya. Yang terjadi di lapangan adalah bahwa kelembagaan HTR di daerah penelitian merupakan kelembagaan baru yang sengaja dibuat demi kepentingan pelaksanaan HTR. sebanyak $72,6 \%$ responden merasa peran KTH penting. Dengan adanya kelompok tani hutan, proses pengurusan ijin HTR menjadi lebih mudah dan informasi tentang HTR juga mudah diperoleh. 


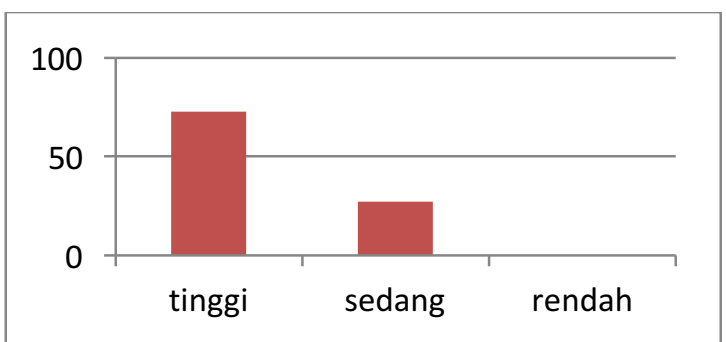

Gambar 8. Persepsi Masyarakat terhadap Kelembagaan Hutan

Walaupun mereka setuju dengan peran $\mathrm{KTH}$, namun mereka merasa belum saling mengenal antar satu anggota dengan anggota yang lain. Hal ini wajar dikarenakan mengingat kelembagaan KTH yang mereka bentuk baru. Selain itu, mereka juga beranggapan bahwa keaktifan setiap anggota kelompok dalam kelompoknya sangat rendah. KTH selama ini baru berperan dalam proses pengajuan ijin dan dapat dibilang bahwa yang berperan hanya anggota tertentu saja dan ketua nya, sedangkan dalam kegiatan lainnya peran KTH belum terilihat. Di Desa Sinar Ogan, Budi Lestari, Srikaton, Jati Indah, dan Jati Baru, frekuensi pertemuan antar anggota kelompok maupun antar kelompok sangat tinggi pada saat proses pengajuan baru berjalan. Namun begitu ijin telah keluar, frekuensi pertemuan tersebut menurun dengan drastis bahkan hampir tidak pernah dilakukan lagi.

\section{h. Persepsi Masyarakat terhadap Tenaga Pendamping}

Pendampingan dibutuhkan untuk menunjang kegiatan HTR. Pendampingan HTR dilakukan oleh penyuluh kehutanan dan pihak dari KPH Gedong Wani sendiri.

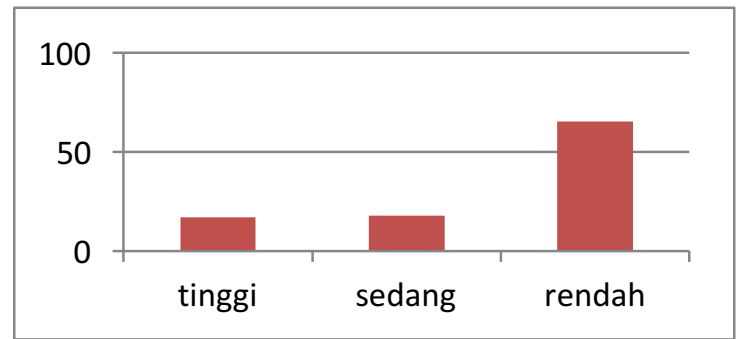

Gambar 10. Persepsi Masyarakat terhadap Tenaga Pendamping

Berdasarkan gambar 10, persepsi masyarakat terhadap tenaga pendamping sebanyak $16,8 \%$ responden berpesepsi tinggi. Menurut responden dalam kategori ini, jumlah tenaga pendamping HTR selama ini telah memadai. Tenaga pendamping juga menguasai materi serta dalam penyampaian materi disesuaikan dengan latar belakang dan kemampuan masyarakat. Sedangkan sebanyak $17 \%$ resonden termasuk golongan persepsi sedang, dan sebanyak $62 \%$ responden masuk ke dalam golongan persepsi rendah. Hal ini dikarenakan masyarakat merasa bahwa jumlah tenaga pendamping dan materi yang diberikan masih kurang.

Saat ini, pendampingan yang berjalan baru bersifat teknis. Untuk pendampingan yang bersifat non teknis seperti penguatan kelembagaan masih sangat kurang. Padahal penguatan kelembagaan merupakan faktor penting dalam menyiapkan masyarakat untuk mengelola HTR (Hakim, 2009). Hal ini perlu diperhatikan, karena pendampingan penguatan kelembagaan dapat membangun masyarakat yang mandiri dalam mengelola hutan. 


\subsection{Faktor-Faktor yang Mempengaruhi Persepsi Masyarakat}

Tabel 1. Hasil Uji T pengaruh variabel tak bebas (persepsi) terhadap variabel bebas (faktor-faktor yang mempengaruhi persepsi)

\begin{tabular}{lll}
\hline \multicolumn{1}{c}{ Variabel Bebas } & \multicolumn{1}{c}{ Koefisien Regresi } & Pvalue \\
\hline Umur $\left(\mathrm{X}_{1}\right)$ & $-0,421$ & 0,523 \\
\hline Pendidikan formal $\left(\mathrm{X}_{2}\right)$ & $-1,563$ & 0,038 \\
\hline Pendidikan informal $\left(\mathrm{X}_{3}\right)$ & 2,443 & 0,042 \\
\hline Luas lahan HTR $\left(\mathrm{X}_{4}\right)$ & $-2,450$ & 0,001 \\
\hline Jarak ke lahan HTR $\left(\mathrm{X}_{5}\right)$ & 0,801 & 0,250 \\
\hline Pendapatan $\left(\mathrm{X}_{6}\right)$ & 2,384 & 0,001 \\
\hline Jumlah tanggungan $\left(\mathrm{X}_{7}\right)$ & $-0,552$ & 0,614 \\
\hline Ketersediaan info $\left(\mathrm{X}_{8}\right)$ & 3,013 & 0,000 \\
\hline Intensitas penyuluhan $\left(\mathrm{X}_{9}\right)$ & 1,654 & 0,029 \\
\hline Konstanta & 54,706 & 0,000 \\
\hline F hitung & 9,812 & 0,000 \\
\hline$R$ & 0,714 & \\
\hline R Square & 0,510 & \\
\hline
\end{tabular}

Seberapa besar pengaruh variabel bebas terhadap variabel tak bebas(persepsi) dilakukan analisis lanjutan dengan tahapan memasukkan semua variabel bebas, kemudian dilakukan analisis. Berdasarkan hasil uji statistik pada tabel 1 , tidak semua variabel bebas menunjukkan peran yang nyata sebagai penduga variabel tak bebas. Hasilnya adalahvariabel umur $\left(X_{1.1}\right)$, jarak ke lahan $\operatorname{HTR}\left(X_{1.5}\right)$, dan jumlah tanggungan $\left(X_{1.7}\right)$ dinyatakan sebagai variabel bebas yang tidak berpengaruh nyata terhadap persepsi responden. Sedangkan untuk variabel pendidikan formal $\left(X_{1.2}\right)$, pendidikan informal $\left(X_{1.3}\right)$, luas lahan $\operatorname{HTR}\left(X_{1.4}\right)$, pendapatanper bulan $\left(X_{1.6}\right)$, ketersediaan info $\left(X_{1.8}\right)$, dan intensitas penyuluhan $\left(X_{1.9}\right)$ dinyatakan sebagai variabel bebas yang berpengaruh nyata terhadap persepsi responden terhadap pembangunan HTR. Oleh karena itu didapatkan persamaan sebagai berikut :

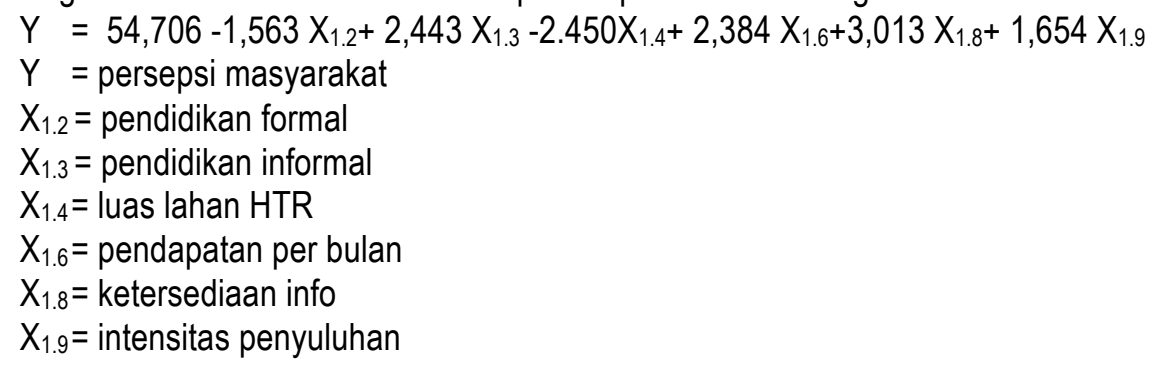

Besarnya pengaruh faktor-faktor persepsi sebagai variabel bebas terhadap persepsi masyarakat terhadap pembangunan hutan tanaman rakyat sebagai variabel tak bebas dijelaskan sebagai berikut :

\section{a. Pengaruh Pendidikan Formal terhadap Tingkat Persepsi}

Dari hasil uji statistik, pendidikan formal masyarakat berpengaruh nyata terhadap tingkat persepsi masyarakat terhadap pembangunan hutan tanaman rakyat. Dari tabel 2 , sebanyak $35,8 \%$ 
responden mengikuti pendidikan formal selama kurang dari 6 tahun, $34,7 \%$ responden mengikuti pendidikan formal dalam rentang waktu 6 sampai 9 tahun, dan sebanyak $29,5 \%$ responden mengikuti pendidikan formal lebih dari 9 tahun.

Tabel 2. Distribusi Responden Berdasarkan Pendidikan Formal

\begin{tabular}{lllll} 
Variabel & Kategori & & $\mathrm{N}$ & $\%$ \\
\hline Pendidikan & $<6$ tahun & Rendah & 34 & 35,8 \\
\cline { 2 - 5 } Formal & $6-9$ tahun & sedang & 33 & 34,7 \\
\cline { 2 - 5 } & $>9$ tahun & Tinggi & 28 & 29,5
\end{tabular}

Terbatasnya pendidikan yang pernah dicapai mengakibatkan kemampuan dan wawasan berpikir petani hutan tanaman raktat relatif terbatas. Petani berpendidikan rendah, tidak sekolah, atau tidak tamat SD, cenderung sulit menerima gagasan baru dalam program pembangunan hutan tanaman rakyat. Sebaliknya petani yang mempunyai pendidikan yang lebih tinggi, tamat SMP atau tamat SMU mempunyai wawasan dan pengetahuannya lebih tinggi.Dengan semakin luasnya wawasan dan pengetahuan petani mengakibatkan relatif lebih cepat melihat adanya kesempatan atau peluang dalam peningkatan ekonomi (Yuwono, 2006).

\section{b. Pengaruh Pendidikan Informal terhadap Tingkat Persepsi}

Dari tabel 3, menunjukkan bahwa sebanyak $85,3 \%$ responden tidak pernah mengikuti pendidikan informal, seperti pelatihan, kursus, dan training. Sedangkan responden yang pernah mengikuti pendidikan informal sebanyak 1 sampai 3 kali berjumlah 14,7\% responden. Dari hasil uji statistik, pendidikan informal berpengaruh nyata terhadap tingkat persepsi responden terhadap pembangunan hutan tanaman rakyat. Pendidikan informal berfungsi untuk meningkatkan pengetahuan masyarakat mengenai hutan. Melalui pendidikan informal seperti pelatihan, kursus, dan training, maka akan membantu masyarakat lebih terbuka dan menerima tentang gagasan mengenai hutan tanaman rakyat.

Tabel 3. Distribusi Responden Berdasarkan Pendidikan informal

\begin{tabular}{lllll}
\hline Variabel & Kategori & & $\mathrm{N}$ & $\%$ \\
\hline $\begin{array}{l}\text { Pendidikan } \\
\text { Informal }\end{array}$ & tidak pernah & Rendah & 81 & 85,3 \\
\cline { 2 - 5 } & $1-3$ kali & sedang & 14 & 14,7 \\
\cline { 2 - 5 } & $>3$ kali & Tinggi & 0 & 0 \\
\hline
\end{tabular}

Sebagai implikasi untuk meningkatkan persepsi maka tingkat pendidikan harus ditingkatkan, tetapi karena tidak memungkinkan lagi untuk mengikuti pendidikan formal, maka kursus atau pelatihan petani yang relevan perlu diberikan. Dari hasilpenelitian sebagian responden belum pernah mengikuti pelatihan hutan tanaman rakyat.

\section{c. Pengaruh Luas Lahan HTR terhadap Tingkat Persepsi}

Dalam tabel 4, sebanyak 46,3\% responden memiliki lahan HTR kurang dari $2 \mathrm{Ha}$, sebanyak 48,4\% responden memiliki lahan HTR antara 2 sampai $3 \mathrm{Ha}$, dan sisanya sebanyak 5,3\% responden 
memiliki lahan HTR lebih dari $3 \mathrm{Ha}$. Dari hasil uji statistik, luas lahan HTR berpengaruh nyata terhadap tingkat persepsi masyarakat terhadap pembangunan hutan tanaman rakyat.

Tabel 4. Distribusi Responden Berdasarkan Luas Lahan HTR

\begin{tabular}{lllll}
\hline Variabel & Kategori & & N & $\%$ \\
\hline \multirow{2}{*}{ Luas Lahan } & $<2$ ha & Rendah & 44 & 46,3 \\
\cline { 2 - 5 } & $2-3$ ha & sedang & 46 & 48,4 \\
\cline { 2 - 5 } & $>3$ ha & Tinggi & 5 & 5,3 \\
\hline
\end{tabular}

Semakin luas lahan, persepsi masyarakat semakin rendah. Hal ini disebabkan karena adanya kekhawatiran masyarakat terhadap penguasaan lahan dan hasil panen. Alasan lain adalah semakin luas lahan, beban tanggung jawab mereka semakin besar dengan adanya aturan PSDH. Semakin luas lahan, maka tanggungan PSDH nya pun makin besar pula.

\section{d. Pengaruh Pendapatan per Bulan terhadap Tingkat Persepsi}

Dari tabel 5 , menunjukan sebanyak $58,9 \%$ responden berpendapatan kurang dari satu juta per bulan dan tergolong rendah, sebanyak $27,4 \%$ responden berpendapatan antara 1 sampai 3 juta per bulan dan tergolong sedang, sedangkan sebanyak $13,7 \%$ responden berpendapatan lebih dari tiga juta rupiah per bulan. Dari hasil uji statistik, pendapatan per bulan ini berpengaruh nyata terhadap persepsi masyarakat terhadap pembangunan hutan tanaman rakyat.

Tabel 5. Distribusi Responden Berdasarkan Pendapatan per Bulan

\begin{tabular}{|c|c|c|c|c|c|}
\hline Variabel & & Kategori & & $\mathrm{N}$ & $\%$ \\
\hline \multirow{3}{*}{$\begin{array}{l}\text { Pendapatan } \\
\text { bulan }\end{array}$} & \multirow[t]{3}{*}{ per } & $<1$ juta & Rendah & 56 & 58,9 \\
\hline & & 1-3 juta & sedang & 26 & 27,4 \\
\hline & & $>3$ juta & Tinggi & 13 & 13,7 \\
\hline
\end{tabular}

Sumber pendapatan responden sebagian besar berasal dari getah karet baik yang berasal dari lahan sendiri dan juga dari sebagai buruh. Mereka berharap dengan mengikuti program hutan tanaman rakyat ini, dapat meningkatkan pendapatan mereka. Dengan ikut HTR mereka berharap mendapatkan insentif modal, bibit atau pengetahuan untuk mengelola lahannya dengan lebih baik.

\section{e. Pengaruh Ketersediaan Informasi tentang HTR terhadap Tingkat Persepsi}

Berdasarkan tabel 6, sebanyak 50, $5 \%$ responden tergolong rendah dalam hal mendapatkan informasi mengenai program HTR, sebanyak 46,3 \% responden tergolong sedang dan 3,2 \% responden tergolong tinggi dalam hal mendapatkan informasi mengenai HTR. Berdasarkan hasil uji statistik, ketersediaan informasi berpengaruh nyata terhadap tingkat persepsi masyarakat terhadap program HTR. 
Tabel 6. Distribusi Responden Berdasarkan Ketersediaan Informasi

\begin{tabular}{lllll} 
Variabel & Kategori & & $\mathrm{N}$ & $\%$ \\
Ketersediaan & $1-3$ & Rendah & 48 & 50,5 \\
\cline { 2 - 5 } Info & $3-6$ & sedang & 44 & 46,3 \\
\cline { 2 - 5 } & $>6$ & Tinggi & 3 & 3,2 \\
\hline
\end{tabular}

Dikarenakan ketersediaan informasi yang diterima masyarakat kurang,maka persepsi masyarakat terhadap program ini cukup rendah. Ketersediaan informasi mengenai HTR hanya didapatkan masyarakat dari penyuluhan dan sosialisasi. Mayoritas responden belum memiliki inisiatif untuk mencari tahu lebih jauh mengenai program HTR ini.

\section{f. Pengaruh Intensitas Penyuluhan HTR terhadap Tingkat Persepsi}

Berdasarkan tabel 7 , sebanyak $48,4 \%$ responden berpendapat bahwa intensitas penyuluhan yang diberikan selama ini tergolong rendah dan sedang, sebanyak 3,2\% responden berpendapat bahwa intensitas penyuluhan selama ini tergolong tinggi. Berdasarkan hasil uji statistik, intensitas penyuluhan HTR berepengaruh nyata terhadap tingkat persepsi.

Tabel 7. Distribusi Responden Berdasarkan Intensitas Penyuluhan

\begin{tabular}{lllll} 
Variabel & Kategori & & $\mathrm{N}$ & $\%$ \\
\hline Intensitas & Tidak pernah & Rendah & 46 & 48,4 \\
\cline { 2 - 5 } Penyuluhan & Kadang-kadang & sedang & 46 & 48,4 \\
\cline { 2 - 5 } & Sering & Tinggi & 3 & 3,2 \\
\hline
\end{tabular}

Dikarenakan kurangnya intensitas penyuluhan yang diberikan pihak terkait, maka pemahaman masyarakat tentang program HTR sangat rendah. Ketersediaan informasi berpengaruh nyata terhadap tingkat persepsi masyarakat. keterkaitan antara ketersediaan informasi dengan intensitas penyuluhan dirasakan sangat berpengaruh, dikarenakan intensitas penyuluhan yang rendah, maka ketersediaan informasi yang didapat masyarakat pun juga rendah, sehingga persepsi yang dibangun pun juga rendah.

\section{KESIMPULAN}

Tingkat persepsi masyarakat terhadap program pembangunan HTR tergolong dalam kategori sedang. Masyarakat merasa mendapatkan manfaat dengan adanya program ini yaitu jaminan keamanan. Aturan yang ditetapkan oleh Pemerintah juga tidak memberatkan masyarakat, seperti dalam hal pengurusan ijin beserta persyaratan dan juga jenis tanaman yang telah ditetapkan. Faktorfaktor yang berpengaruh nyata dalam mempengaruhi persepsi masyarakat terhadap program pembangunan HTR adalah pendidikan formal, pendidikan informal, luas lahan HTR, pendapatan per bulan, ketersediaan info, intensitas penyuluhan. Semakin tinggi tingkat pendidikan terdapat kecenderungan semakin meningkat persepsi. Pendidikan informal yang semakin banyak dilakukan menyebabkan persepsi semakin tinggi. Semakin sempit lahan, persepsi masyarakat semakin tinggi. Semakin tinggi pendapatan semakin tinggi persepsi masyarakat. dalam hal ketersediaan info dan 
intensitas penyuluhan, semakin tinggi ketersediaan info dan intensitas penyuluhan semakin tinggi persepsi masyarakat terhadap pembangunan HTR.

\section{DAFTAR PUSTAKA}

Ahmad, M. F., Yusran, Y., \& Mas'ud, E. I. (2017). Penilaian Aspek Hukum Tata Kelola Hutan Tanaman Rakyat di Kabupaten Barru. Jurnal Hutan dan Masyarakat. Vol, 9(1), 8-16.

Desmiwati, N. F. N. (2016). Studi Tentang Persepsi dan Tingkat Partisipasi Petani Penggarap di Hutan Penelitian Parungpanjang." Jurnal Perbenihan Tanaman Hutan 4.2): 109-124.

Dishut Provinsi Lampung. (2013). Tata Hutan dan Rencana Pengelolan Hutan Jangka Panjang 20142023 UPTD KPHP Gedong Wani, Dinas Kehutanan Provinsi Lampung. Bandar Lampung

Ekawati S, Daryono H, Zuraida. (2008). Kesiapan Masyarakat Sekitar Hutan dalam Pembangunan Hutan Tanaman Rakyat. Makalah Seminar Hutan Tanaman Rakyat yang diselenggarakan oleh Puslit Sosek dan Kebijakan Kehutanan Badan Litbang Kehutanan tanggal 14 Agustus 2008

Fabra-Crespo, M., Mola-Yudego, B., Gritten, D., \& Rojas-Briales, E. (2012). Public perception on forestry issues in the Region of Valencia. Forest Systems, 21(1), 99-110

Hakim I. (2009). Kajian Kelembagaan dan Kebijakan Hutan Tanaman Rakyat. Jurnal Analisis Kebijakan Kehutanan Vol 6 No.1: 27-41

Robbins, S. P., dan Judge, T. A. (2006). Perilaku organisasi. Edisi Bahasa Indonesia. Jakarta. PT. Indeks Kelompok Gramedia.

Senoaji, G. (2011). Kondisi Sosial Ekonomi Masyarakat Sekitar Hutan Lindung Bukit Daun di Bengkulu. Sosiohumaniora, 13(1), 1

Sumanto, S. E. (2009). "Kebijakan pengembangan perhutanan sosial dalam perspektif resolusi konflik." Jurnal Analisis Kebijakan Kehutanan 6.1

Wulandari, C. (2010). Studi Persepsi Masyarakat tentang Pengelolaan Lanskap Agroforestry di Sekitar Sub Das Way Besai, Provinsi Lampung. Jurnal IImu Pertanian Indonesia. Vol 15 No.3

Yuwono, S. (2006). Persepsi dan Partisipasi Masyarakat Terhadap Pembangunan Hutan Rakyat Pola Kemitraan di Kabupaten Musi Rawas Provinsi Sumatera Selatan. Bogor: Sekolah Pascasarjana, Institut Pertanian Bogor. 